\title{
Case Study: Finding Better Solutions for Municipal Solid Waste Management in a Semi Local Authority in Sri Lanka
}

\author{
Bandunee Champika Liyanage ${ }^{1}$, Renuka Gurusinghe ${ }^{1}$, Sunil Herat ${ }^{2}$, Masafumi Tateda ${ }^{3}$ \\ ${ }^{1}$ Department of Civil Engineering, Faculty of Engineering Technology, The Open University of Sri Lanka, Nawala, \\ Nugegoda, Sri Lanka \\ ${ }^{2}$ Griffith School of Engineering, Nathan Campus, Griffith University, Queensland, Australia \\ ${ }^{3}$ Department of Environmental Engineering, Toyama Prefectural University, Toyama, Japan \\ Email: bcliy@ou.ac.lk
}

Received 7 February 2015; accepted 25 February 2015; published 26 February 2015

Copyright (C) 2015 by authors and Scientific Research Publishing Inc.

This work is licensed under the Creative Commons Attribution International License (CC BY).

http://creativecommons.org/licenses/by/4.0/

(c) (i) Open Access

\begin{abstract}
This case study investigates better and sustainable waste management for a given area in Sri Lanka. A questionnaire and field surveys were performed in a small local authority adjacent to Colombo, the capital city. Composting for organic waste and incineration for non-compostable waste were found to be important treatment methods for solid-waste management. The reduction of solid waste is a critical process for sustainable management. Currently, people in the area do not have much interest in waste recycling to decrease the cost of solid-waste management. It was therefore concluded that raising people's awareness would play an important role in the reduction of solid waste. A suitable waste-management plan needs to be made for each community and area. The situation and conditions of every area is different, therefore each community needs to make an effort to find its own better and sustainable solid-waste management process.
\end{abstract}

\section{Keywords}

Pradeshiya Sabha, Sri Lanka, Solid Waste, Questionnaire, Field Survey, Awareness

\section{Introduction}

A variety of studies on solid-waste management in developing countries have been conducted in recent years. Some researchers have looked at the influence of education to waste management [1]-[3], while others have investigated policy making for waste management in specific areas or countries [4]-[8]. Health and risk considera- 
tions around waste management have also been the focus of studies [9]-[12], while current systems of waste management in particular areas or countries have been analyzed [13]-[16]. Finally technology and engineering in waste management have discussed by some [17]-[19].

Solid-waste management, especially in developing countries, poses particular problems for each local community, so empirical field investigations are invariably required to solve particular local issues. Solid-waste management is emerging as a major problem for policy makers in developing countries as the quantity of solid waste generated has increased significantly and its characteristics have changed as a result of changes in peoples' lifestyles due to swift industrialization and urbanization. Rapid population growth and an increase in economic activities combined with a lack of education in modern solid-waste management practices, complicate efforts to improve the situation in these countries. Compared to high-income residents in developed countries, the urban residents of developing countries produce less solid waste per-capita. However, the capacity of developing countries to collect, process, dispose, or reuse the waste in a sustainable manner is highly limited. Recent studies have demonstrated the lack of capacity of local authorities to deal with this emerging issue and have recommended improvements at all levels of the administration systems to achieve a sustainable solution to the problem [4] [20] [21].

Several studies on waste management specifically related to Sri Lanka have been undertaken. Mallawarachchi and Karunasena (2012) discussed national policy enhancement on e-waste in Sri Lanka [22]. Solid-waste management conditions in Sri Lanka were reported by several researchers [20] [22]. A study conducted by Vidanaarachchi et al. (2006) especially showed that common causes of poor waste management in Sri Lanka are the lack of appropriate policies and legislation, lack of political and public commitment, and inadequate technical expertise at the local authorities [20]. Therefore, the development and implementation of appropriate policies, political will, and public commitment are essential in order to reduce environmental, social, and economic problems associated with the present disposal practices. In countries such as Sri Lanka, the problems associated with solid waste lie more with the present haphazard disposal practices than with the rate of generation. Therefore policies should be formulated to encourage solid-waste management practices through waste avoidance and reduction, re-use and recycling, and thereafter final disposal in an environmentally friendly manner.

The aim of this paper is to propose a solid-waste management program to eliminate the unsustainable wastedisposal methods practiced in a small local authority adjacent to Colombo, the capital city of Sri Lanka. The study focuses on identifying problems and finding solutions by conducting a questionnaire and pilot scale projects in the area, then proposing a municipal waste-management program that prioritizes waste reduction at source rather than recycling at end-of-life disposal. This study may also be relevant to similar local authorities in other developing countries.

\section{Background Information}

\subsection{Country Profile of Sri Lanka}

The Democratic Socialist Republic of Sri Lanka is located off the southeastern coast of India and covers an area of $65,610 \mathrm{~km}^{2}$ between $5^{\circ} 55^{\prime} \mathrm{N}$ and $9^{\circ} 55^{\prime} \mathrm{N}$ and $79^{\circ} 41^{\prime} \mathrm{E}$ and $81^{\circ} 54^{\prime} \mathrm{E}$. The Palk Strait separates Sri Lanka from India. Figure 1 shows a map of Sri Lanka with its nine provinces, three districts of western province (WP) and nine local authorities in Colombo District. Sri Lanka's population was approximately 20 million in 2012 with a per capita gross national product (GNP) of US\$1395 and a growth rate of 7.7\% [23].

\subsection{Local Government Structure}

In 1987, Sri Lanka underwent decentralization of its government structure with the setting up of Provincial Councils responsible for carrying out activities planned by central government ministries and their departments and agencies. Currently there are nine Provincial Councils in Sri Lanka. The Provincial Councils comprise Municipal Councils (population of over 30,000), Urban Councils (population of between 10,000 and 30,000) and Divisional Councils (Pradeshiya Sabhas or Pradesha Sabhai) for smaller towns and rural areas. Currently there are 23 Municipal Councils, 41 Urban Councils, and 271 Divisional Councils. The Provincial Councils are responsible for supervising the functioning of these lower authorities, including their solid-waste management.

\subsection{Present Scenario of Solid-Waste Management in Sri Lanka}

1) Waste generation 


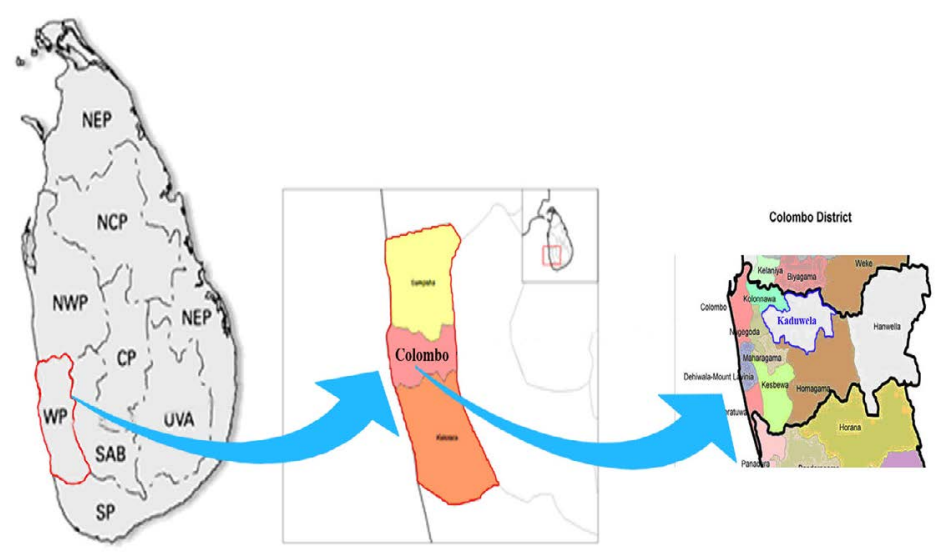

Figure 1. Map of Sri Lanka with provinces and selected districts and local authorities.

The quantity of municipal solid waste (MSW) generated in Sri Lanka has increased over the years with the growth of consumption patterns. Analysis of data has revealed that the amount of MSW per capita per day on average was $0.85 \mathrm{~kg}$ in Colombo Municipal Council, $0.75 \mathrm{~kg}$ in other Municipal Councils, $0.60 \mathrm{~kg}$ in Urban Councils, and $0.40 \mathrm{~kg}$ in Pradeshiya Sabhas. The primary sources of MSW are households and commercial establishments, while secondary sources are industries and hospitals. The major portion of the MSW stream in Sri Lanka is dominated by organic waste generated from households, markets, and slaughterhouses (Figure 2). The organic portion consists of banana stalks and logs, tree cuttings, sawdust, wood chips, and paddy husks- excluding coconut shells. The organic waste is further grouped into long-term and short-term biodegradable. The former cannot be degraded easily within 2 - 3 months and is initially used as a bulking material in the composting process. The latter can be degraded within 1 - 2 months or even less. The moisture content and organic fraction of the MSW stream were significantly high with low calorific values.

2) Recycling practice

In Sri Lanka, waste separation at source is still not practiced on a large scale. Of the total MSW generated only $10 \%-40 \%$ is collected and the rest remains either piled up on the streets or dumped in low-lying areas, such as marshes and abandoned paddy fields. SWM practices in various local authority areas differ greatly. Although regular solid-waste collection systems exist in larger council areas, there is virtually no collection system in some of the smaller jurisdictions. The ratio of waste collected to waste generated ranges from approximately 93\% in Colombo Municipal Council to as little as 5\% in some of the smaller urban areas. In Sri Lanka, resource recovery from MSW has been developed informally over the past few years for certain type of materials. Scavengers collect glass, paper, plastics, metals, etc. Currently, recycling of materials is carried out through an informal market system. Items are recovered at various points of the waste stream: at household level, during collection and transport by local authority workers, or at the final disposal site by waste pickers and municipal workers. The retrieved materials are sold to collection shops where they are cleaned and sold for recycling by local industrialists, or exported overseas. Also about 5\% of the collected MSW is processed in various households and central composting systems. Household-level composting has proved more successful than centralized composting projects. The limited success of centralized composting is due to unsuitable locations and public protest against malodor and contamination of water bodies.

3) Disposal practice

The most common method of final disposal of MSW is an open dumping, which accounts for more than 85\% of the collected waste. These are non-engineered sites where waste is tipped haphazardly without environmental protection. The majority of open dumps are in the low-lying areas-marshes and abandoned paddy fields that are filled with solid waste primarily as a means of land reclamation. Some of the local authorities use a daily topsoil cover to reduce nuisance and allay public opposition. These dumps are used to dispose of every type of waste, including industrial, hospital and clinical, and slaughterhouse wastes, together with MSW, without any proper segregation. None of the open dump sites is engineered to manage the leachate or control pollutants released from waste decomposition. Few or no basic operations exist, such as leveling or covering of waste at the site, 


\section{DOMESTIC WASTE COMPOSITION IN SRI LANKA}

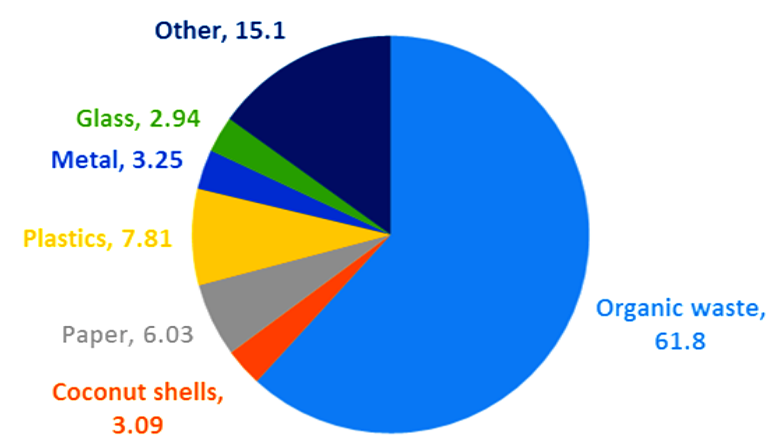

Figure 2. Domestic waste composition.

presumably due to the high costs involved. Soil cover is applied only at the final stage when there is a projected use of the land or public pressure. In addition to dumpsites operated by the relevant authorities, random dumping by private individuals takes place along streets, and on marshes and abandoned paddy fields. In the central part of the country, waste is mostly disposed of along the roads. Local authorities with regular responsibility take little control over these malpractices, mainly because ofa lack of resources or stringent laws.

4) Current problems

Financial provisions for SWM in Sri Lanka generally fall under the health section of the annual budget of the local authority. The main source of revenue for local authorities is through property rates and taxes, supplemented by central government grants. There is no specification in the budget allotment for the various tasks involved in SWM. However, it has been estimated that local authorities spend around 3\% - 15\% of their total budget on SWM. Practically all the local authorities spend more than $80 \%$ of the allotted budget in collection and transportation of refuse, of which a significant amount goes to salaries, allowances, wages, maintenance, and fuel costs. Most local authorities, with the exception of Municipal Councils and Urban Councils, spend hardly money on disposal, since the wastes are hastily dumped without spreading and compaction. The accumulation of uncollected MSW in public places and the improper handling of MSW during transportation, disposal, and scavenging have become major health and safety issues in Sri Lanka. Insects, rodents, and other vectors are attracted to the waste and can spread communicable diseases, such as cholera and dengue fever. Furthermore, use of water polluted by solid waste for bathing, cooking, irrigation, and drinking could expose individuals to diseases, pathogens, and other contaminants. Various diseases are spread via the fecal-oral route facilitated by unsafe water supplies and inadequate sanitary conditions. A lack of understanding of the causes of diseases related to garbage coupled with the existing bureaucratic approach to managing MSW, means the significance of health impacts and the potential threat to workers in the waste stream are often not recognized. For these reasons health aspects are often neglected by the government and the authorities.

Obstacles to implementing proper solid-waste management systems by local authorities in Sri Lanka include inadequate facilities for final disposal; introduction of improper solid waste management; lack of knowledge, technology and expertise about waste; poor planning and management; high cost of collection; and the attitude of people towards waste.

\section{Research Methods}

\subsection{Study Area}

The study area is in Kaduwela, Pradeshiya Sabha, which has a population of 252,041 (Department of Census and Statistics Sri Lanka, 2012) and is divided into three public health inspector divisions. The area is highly residential, having better infrastructure compared to the other parts of the country. The average daily waste generation is approximately 35 metric tons, which is gathered in a dumping area. The waste comprises both combustible and non-combustible materials generated from market stalls, households, and industrial sections. The 
dumped waste is then taken by Burns Environmental Technologies Ltd. (BETL), a private company. The Pradeshiya Sabha pays US\$9 per metric ton to BETL and has to spend nearly US $\$ 10,000$ per month on waste management. Despite this, large amounts of waste still go to the dumping area.

\subsection{Questionnaire}

In order to obtain both qualitative and quantitative data, a questionnaire survey was conducted. The questionnaire was carried out with a random sample of 150 families totaling 750 residents from Battaramulla area, a major town in the Kaduwela Pradeshiya Sabha. The survey focused on the present MSW disposal practices of the residential community, their habits and attitude to solid waste, and the level of involvement of recycling, including home composting. The questionnaire method involved distributing questionnaires to representatives of each family and then organized a meeting of all respondents to collect the information individually. This resulted in a return of $100 \%$.

\subsection{Field Observations}

Field observations were made on the quantity and composition of MSW in the same community that responded to the questionnaire. Initially the selected community was instructed to practice waste separation through an awareness program. The sorted waste was then transported weekly to the site and an analysis made for a month to determine the average daily values. The data obtained from this analysis comprised the composition of the waste, the quantities of waste available for recycling and incineration, and the moisture content. In addition, a detailed study of the waste collection system in Battaramulla town was completed.

\subsection{Pilot Scale Practices}

The proposed pilot project attempted to develop a better solid waste management system for a small local authority. The solid-waste management program for the treatment and disposal of waste suggested the following methods.

1) Home composting

Figure 3 shows the compost container selected for the project. The container was made of plastic and measured 1'6" $\times 1$ ' $\times 6$ ". It should not be exposed to rain. The total spending on the containers was about 2 US\$. They had the advantage of being less bulky, portable, and providing quick composting performance, with compost being produced one month after installation. In households of six people about $2 \mathrm{~kg}$ of waste was put in the container per day. As this rate did not fill the container, this size would be suitable for one family.

2) Incineration

Given the category of waste available and the fact complete incineration was desired, a multiple chamber incinerator was selected [24]. The incinerator was designed with a waste feeding-rate of $289 \mathrm{~kg} / \mathrm{hr}$ under a manual batch process. The size of the incinerator was $7^{\prime} \times 7^{\prime} \times 7^{\prime}$ and the daily estimated operating time was 8 hours, using liquid petroleum gas (LPG) as fuel. The incinerator was designed for 15-year performance. The factor of increasing amounts of waste was managed by extending the operating hours of incineration. The temperature inside the secondary chamber was maintained at a level of $1000^{\circ} \mathrm{C}$ in order to destroy any unburned airborne par-
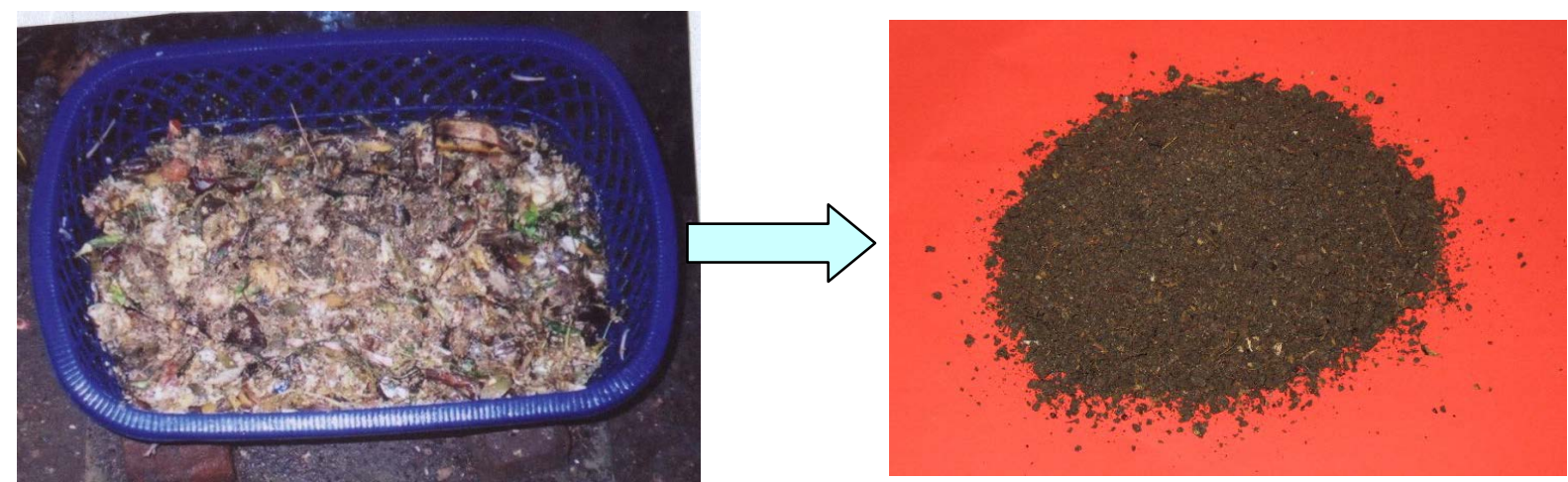

Figure 3. A composting bin. 
ticles. Installation of the incinerator cost approximately four million rupees.

\section{Results and Discussion}

\subsection{Evaluation of Questionnaire Survey Responses}

Figure 4 shows the percentage of the community utilizing each disposal pattern of recyclable waste. Accordingly $38 \%$ practiced recycling mainly metal and glass by giving to scavengers, while $40 \%$ used the government waste-collection system. These results indicate that the public are not concerned with recycling at source, preferring instead to opt for the costly government collection and transporting system. Furthermore, $19 \%$ of the community practice back-yard burning, which can be hazardous to human health because of harmful gas emissions, such as dioxins and furans, resulting from incomplete burning. This also shows that the general public is unaware of the dangers of such improper disposal methods. Figure 5 shows the percentage distribution of recyclable material collection. It indicates that people mainly recycle cardboard and coconut shells. They have not paid any attention to the recycling of other materials, indicating they are less enthusiastic about recycling. The questionnaire also revealed that the public consider the responsibility of waste disposal should be taken by the Pradeshiya Sabha and had a low awareness of solid-waste management, including waste reduction, reuse, and recycling. The survey also revealed that $40 \%$ of families in the community gave their organic waste to the government collection service, while 50\% selected composting (data not shown). Of these, $97 \%$ preferred home composting using compost bins. They used low cost compost bins in preference to bulky bins.

\subsection{Analysis of Field Observations}

According to Figure 2, as the major contributor of the waste stream was highly putrescible organic waste, it was important to promote home composting to divert this waste stream from entering the costly waste collection and disposal system. Accordingly, a suitable low cost compost bin was selected for this purpose. Battaramulla Pra-

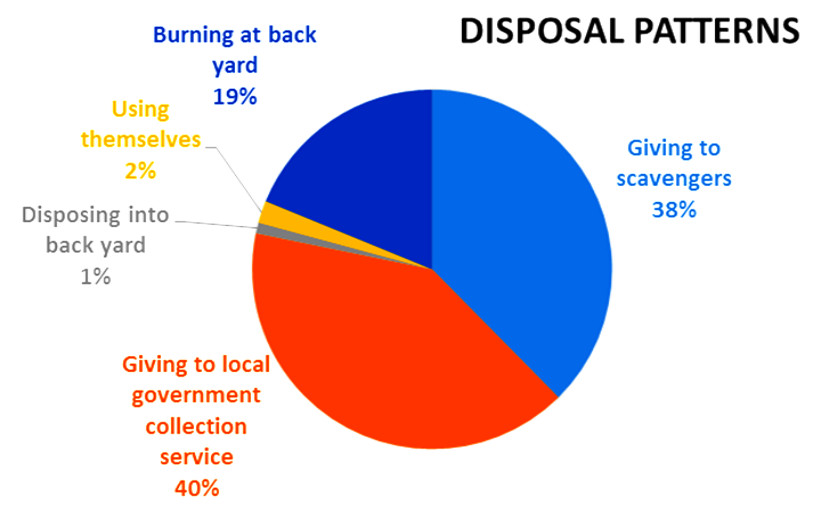

Figure 4. Disposal patterns.

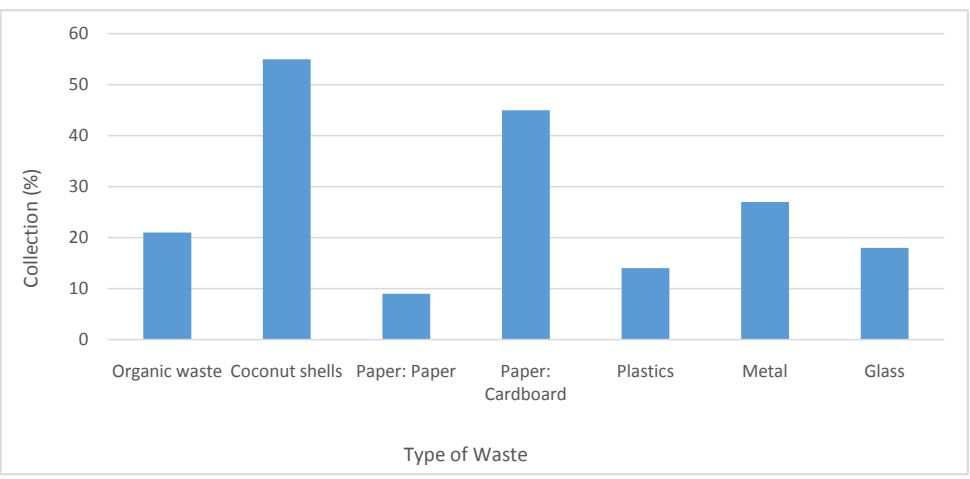

Figure 5. Collection percentage for recycling. 
deshiya Sabha collected domestic waste from supermarkets, garment factories, and hotels. Waste from Kaduwela and Battaramulla areas was transported and dumped at a one-acre site, which created health and environmental problems. About 35 tons of waste was gathered at the site per day. Before the disposal of such a large amount of waste, it is important to have a plan to reduce waste gathered at the site to simplify the process and avoid unnecessary spending. Therefore, attention should be given to reducing the waste. One way of doing this is to reduce waste at the beginning, that is, "at source". As domestic households are the main source of the waste, a "disposal at source" method should be applied. With this aim in mind, a solid-waste management program was carried out for a selected community as part of a pilot project and implemented to some extent by this project by applying proposed solid-waste management.

\subsection{Pilot Scale Practices}

Evaluation of the questionnaire on present disposal practices, along with the high organic composition of the waste, indicated that compost bins were a suitable method for disposal of the organic waste that had already been separated from other waste. The moisture content of the waste was about $65 \%$ - too high for the total waste to be suitable for incinerating, but composting was possible. Implementing such a management program in the whole Battaramulla area up to Kaduwela Pradeshiya Sabha would minimize the waste problem to some extent by virtue of the reduction of waste. The main problem is that the community did not want to buy the bins at such a high cost, although they liked home composting. Hence an experiment was carried out with a lower cost compost bin. This proved successful and compost was produced. With a low cost and easy handling, compost can be improved by trying better operation techniques. The total cost for the bin was only about 265 rupees and therefore affordable.

It is difficult to find a large enough land area in the Battaramulla region as the cost of real estate has increased. Considering the fact an incinerator is proposed as a suitable technique for the ultimate treatment method, it was also observed that $15 \%$ of the waste stream that cannot be reused or recycled contains materials suitable for combustion. Figure 6 shows the amount of combustible waste from 10 representatives from 150 families. Except for "Others" such as clothes/textile, rubber, leather, and so on, all types of waste were constantly generated in almost the same amounts from the first to the fourth weeks. As the total quantity of waste diverted for incineration is about two metric tons per day, an incinerator of less than one metric ton capacity was selected through literature review. The average moisture content of the waste available for incineration was $28 \%$. Since waste for incineration should have a moisture content less than $30 \%$ the sample satisfied the scientific conditions. It was noted that the exhaust emission of incinerating certain waste, such as batteries, is harmful to the environment so it is recommended that further sorting of particularly hazardous waste be undertaken. Due to economic considerations, the feeding method may be manual using backhoes. There should be two or three laborers for the incinerator who can feed the waste manually with a capacity equal to the waste feeding rate. Although the installation cost of an incinerator is high, its operation could reduce environmental health problems expected from the improper management of putrescible solid waste, such as health disorders, sickness, and communicable diseases. The back-yard burning of waste causing air pollution could be banned as the combustible waste can now be sent to the incineration plant.

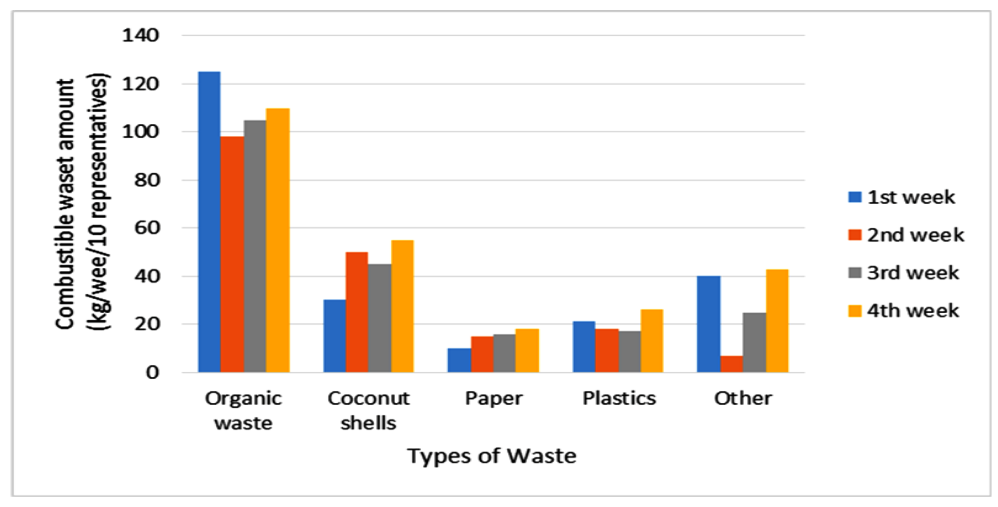

Figure 6. Combustible waste. 


\subsection{Proposed Solid Waste Management Program}

The data analysis in this study indicates that creating awareness among the general public needs to be included in the solutions for the problems mentioned, as well as the provision of disposal methods, such as composting and incineration. Several studies, as listed in the introduction, have mentioned that education to raise awareness is necessary and important for waste management. Furthermore, the effective planning of solid-waste collection is important as this phase requires more than $75 \%$ of the total expenditure in SWM. In the proposed SWM program, special consideration was given to the separation of waste at source for the successful operation of the program. As the flow of some steps of the program depends on the feasibility of waste separation, final disposal methods are only provided for the separated waste stream. For the continuity of the program, follow-up is essential to ensure sustainability of the program and to avoid failure. Considering the above factors, the proposed solid waste management program is shown in Figure 7. An awareness program was carried out in the Battaramulla area based on a successfully implemented example of the community of Vijithapura, a good example society of the selected community. As a result of the implemented program the community has gained knowledge about waste avoidance, reduction, recycling, and waste separation. Also, after the awareness program was undertaken, sorted waste at source was mainly highly compostable—about $62.4 \%$-indicating suitability for composting as a disposal method. Other recyclable wastes, such as glass, metal, and paper should also be given attention.

According to Table 1 income of about 5600 rupees per day can be achieved from recyclable waste. If the recycling project is carried out the 0.5 to 1 ton of waste sent to the site from the Battaramulla area could be reduced instead of being given to the BETL Company. However, a community-based recycling project could not be begun as the majority of the people are middle income and engaged in jobs with the public sector according to the information from the questionnaire and the interviews and the representative persons in the area.

After the community is educated to separate/sort the waste by the proposed solid-waste management program then it will be easy to collect recyclables, and scavengers can be referred to the sorted recyclable waste, as is being done at Vijithapura where these measures have already implemented, then the Pradeshiya Sabha can collect recyclables and obtain an income. However, theft of these recyclable wastes while being transported to the site has become a major problem. Another important factor that should be mentioned is that more than $5600 \mathrm{ru}-$ pees can be earned by recyclables as long as they are not contaminated by waste. Out of the 35 tons taken to the site, about 11 tons (one third of the total waste) are from Battaramulla Pradeshiya Sabha per day. This can be reduced by two tons through incinerating, half a ton by recycling and 8.5 tons by composting. By these means, collection of waste to take to the site can be reduced. In the rolling out of the awareness program, the following should be well organized to gain the maximum participation of the community and prevent unnecessary (or double) effort, time, and expense: maximizing publicity, executing high-quality programs, minimizing the time that people have to spend on waste reduction processes, providing user-friendly leaflets and handouts, providing

\begin{tabular}{|c|c|c|c|c|}
\hline Types of waste & Recyclable materials & $\begin{array}{l}\text { Average amount } \\
\text { (kg/day) }\end{array}$ & $\begin{array}{l}\text { Money conversion rate into } \\
\text { rupees (Rs } / \mathrm{kg} \text { ) }\end{array}$ & Total income per day (Rs/day) \\
\hline \multirow{2}{*}{ Paper } & Cardboard & 287 & 6 & 1719 \\
\hline & Newspapers, magazines, etc. & 25 & 10 & 250 \\
\hline \multirow{5}{*}{ Plastics } & Plastic mega-bottles & 19 & 21 & 399 \\
\hline & $\begin{array}{l}\text { Ice-cream containers, other food } \\
\text { containers, cans }\end{array}$ & 25 & 18 & 450 \\
\hline & Small bottles & 28 & 1 & 28 \\
\hline & Poly sacks/bags & 8 & 2 & 16 \\
\hline & Ferrous metals & 67 & 18 & 1206 \\
\hline \multirow[t]{2}{*}{ Metal } & Other metals, such as aluminium & 13 & 100 & 1300 \\
\hline & Copper & 0.42 & 300 & 128 \\
\hline \multirow[t]{2}{*}{ Glass } & Bottles, grass cup cullet, light bulds, etc. & 58 & 2 & 116 \\
\hline & Total & 530 & & 5612 \\
\hline
\end{tabular}




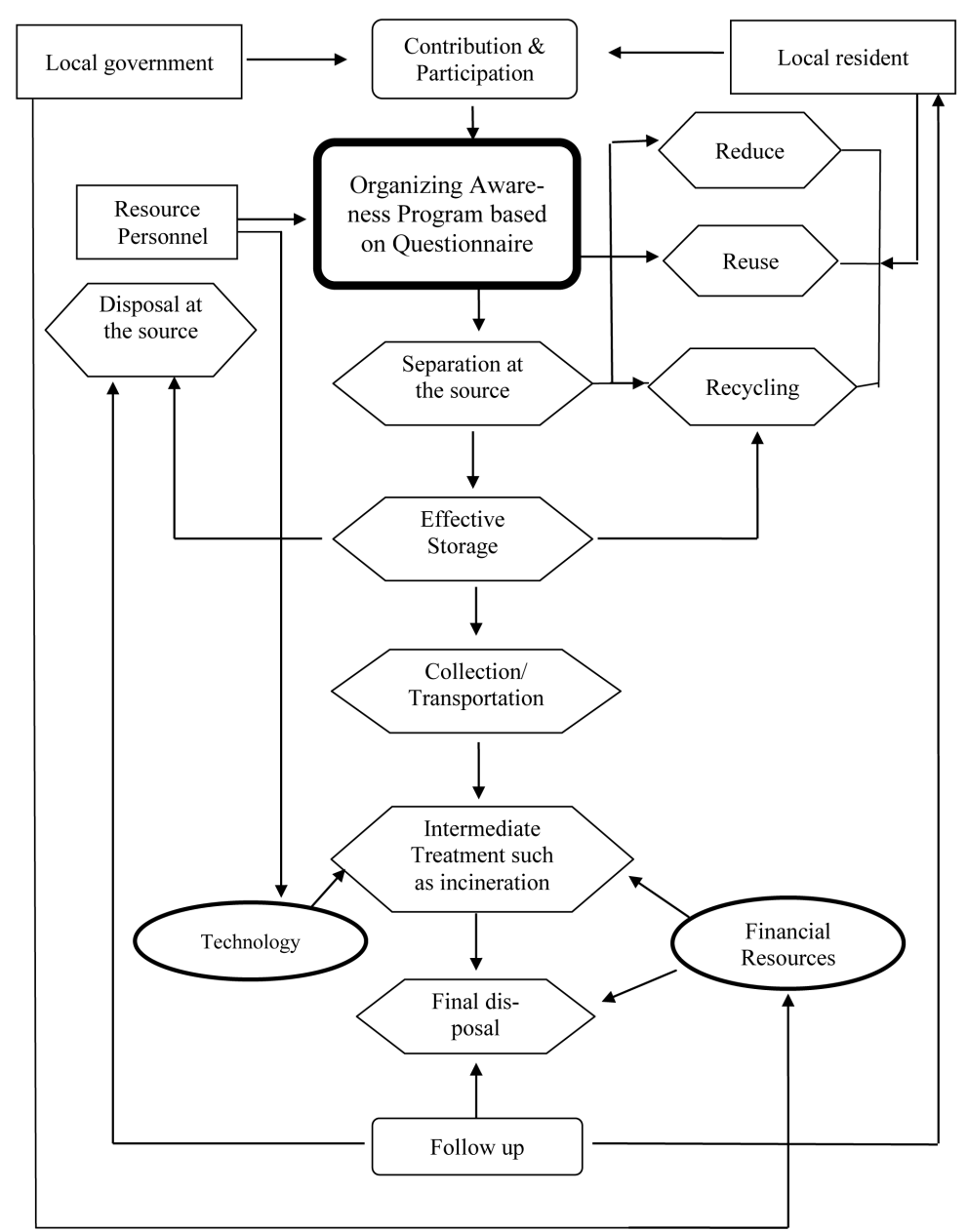

Figure 7. Proposed plan for solid waste management.

easy ways to participate, and gaining good information through questionnaires. Data from the questionnaire provided information on matters that should be considered in organizing awareness programs.

\section{Conclusion}

The study revealed that using solely engineering solutions for solid-waste management is not sufficient. As an example, collection and disposal of all the waste in the area are a complex and large-scale operation and require money to be spent on unnecessary storage, collection, and transportation. If the waste can be disposed of at the source, then waste can be eliminated at the point of generation and there then remains only a small amount for ultimate disposal. As the organic waste composition is high, the most suitable disposal method for the highly putrescible solid waste is composting. People are willing to use compost bins, and they require portable and low cost ones to do so. Hence to satisfy all the requirements, the proposed compost bin is suitable for the disposal of quickly biodegradable organic waste. Incineration is the most suitable method for the disposal of combustible waste. Although the installation cost of an incinerator is high, health and environmental problems will be reduced due to the complete breakdown of pathogens in the process. The bottom ash and fly ash, reduced to $5 \%$ of the input, can be used for land-filling, which is a benefit from incineration. If there is an option for alternative fuels instead of LPG, operating costs can be minimized. Awareness of solid-waste management is necessary and helps to reduce the waste problem in the Battaramulla area.

\section{Acknowledgements}

The authors are thankful to the officials at Pradeshiya Sabha, Kaduwela for their immense support in carrying 
out this project.

\section{References}

[1] Desa, A., Kadir, N.B.A. and Yusooff, F. (2012) Waste Education and Awareness Strategy: Towards Solid Waste Management (SWM) Program at UKM. Procedia-Social and Behavioral Sciences, 59, 47-50. http://dx.doi.org/10.1016/j.sbspro.2012.09.244

[2] Jibril, J.D., Sipan, I.B., Sappi, M., Shika, S.A., Isa, M. and Abdullah, S. (2012) 3R’s Critical Success Factors in Solid Waste Management System for Higher Educational Institutions. Procedia-Social and Behavioral Sciences, 65, 626-631. http://dx.doi.org/10.1016/j.sbspro.2012.11.175

[3] Sekito, T., Prayogo, T.B., Dote, T., Yoshitake, T. and Bagus, I. (2013) Influence of a Community-Based Waste Management System on People’s Behavior and Waste Reduction. Resource, Conservation, and Recycling, 72, 84-90. http://dx.doi.org/10.1016/j.resconrec.2013.01.001

[4] Rushbrook, P.E. and Finnecy, E.E. (1988) Planning for Future Waste Management Operations in Developing Countries. Waste Management \& Research, 6, 1-21. http://dx.doi.org/10.1177/0734242X8800600101

[5] Al-Khatib, I.A., Monou, M., Zahra, A.S.F.A., Shaheen, H.Q. and Kassinos, D. (2010) Solid Waste Characterization, Quantification and Management Practices in Developing Countries. A Case Study: Nablus District-Palestine. Journal of Environmental Management, 91, 1131-1138. http://dx.doi.org/10.1016/j.jenvman.2010.01.003

[6] Zurbrügg, C., Gfrefer, M., Ashadi, H., Brenner, W. and Küpper, D. (2012) Determinants of Sustainability in Solid Waste Management-The Gianyar Waste Recovery Project in Indonesia. Waste Management, 32, 2126-2133. http://dx.doi.org/10.1016/j.wasman.2012.01.011

[7] Menikpura, S.N.M., Sang-Arun, J. and Bengtsson, M. (2013) Integrates Solid Waste Management: an Approach for Enhancing Climate Co-Benefits through Resource Recovery. Journal of Cleaner Production, 58, 34-42. http://dx.doi.org/10.1016/j.jclepro.2013.03.012

[8] Lohri, C.R., Camenzind, E.J. and Zurbrügg, C. (2014) Financial Sustainability in Municipal Solid Waste Management - Costs and Revenues in Bahir Dar, Ethiopia. Waste Management, 34, 542-552. http://dx.doi.org/10.1016/j.wasman.2013.10.014

[9] Arukwe, A., Eggen, T. and Möder, M. (2012) Solid Waste Deposits as a Significant Sources of Contaminants of Emerging Concern to the Aquatic and Terrestrial Environments-A Developing Country Case Study from Owerri, Nigeria. Science of the Total Environment, 438, 94-102. http://dx.doi.org/10.1016/j.scitotenv.2012.08.039

[10] Bleck, D. and Wettberg, W. (2012) Waste Collection in Developing Countries-Tackling Occupational Safety and Health Hazards at Their Source. Waste Management, 32, 2009-2017. http://dx.doi.org/10.1016/j.wasman.2012.03.025

[11] Marshall, R.E. and Farahbakhsh, K. (2013) Systems Approaches to Integrated Solid Waste Management in Developing Countries. Waste Management, 33, 988-1003. http://dx.doi.org/10.1016/j.wasman.2012.12.023

[12] Sasaki, S., Araki, T., Tambunan, A.H. and Prasadja, H. (2014) Household Income, Living and Working Conditions of Dumpsite Waste Pickers in Bantar Gebang: Toward Integrated Waste Management in Indonesia. Resource, Conservation, and Recycling, 89, 11-21. http://dx.doi.org/10.1016/j.resconrec.2014.05.006

[13] Wilson, D.C., Velis, C. and Cheeseman, C. (2006) Role of Informal Sector Recycling in Waste Management in Developing Countries. Habitat International, 30, 797-808. http://dx.doi.org/10.1016/j.habitatint.2005.09.005

[14] Oguntoyinbo, O.O. (2012) Informal Waste Management System in Nigeria and Barriers to an Inclusive Modern Waste Management System: A Review. Public Health, 126, 441-447. http://dx.doi.org/10.1016/j.puhe.2012.01.030

[15] Paul, J.G., Arce-Jaque, J., Ravena, N. and Villamor, S.P. (2012) Integration of the Informal Sector into Municipal Solid Waste Management in the Philippines—What Does It Need? Waste Management, 32, 2018-2028. http://dx.doi.org/10.1016/j.wasman.2012.05.026

[16] Oteng-Ababio, M., Arguello, J.E.M. and Gabbay, O. (2013) Solid Waste Management in African Cities: Sorting the Facts from the Fads in Accra, Ghana. Habitat International, 39, 96-104. http://dx.doi.org/10.1016/j.habitatint.2012.10.010

[17] Ouano, E.A.R. (1988) Review of the Issues in Hazardous and Toxic Waste Management in Developing Countries. Waste Pollution Control in Asia, 433-439.

[18] Vehlow, J. (1998) Waste Management Systems in Industrialized and Developing Countries—Generation, Quality, and Disposal. Proceeding of First International Conference on Environmental Engineering and Renewable Energy, Mongolia, 7-10 September 1998, 405-414. http://dx.doi.org/10.1016/B978-0-08-043006-5.50057-4

[19] Oakley, S.M. and Jimenez, R. (2012) Sustainable Sanitary Landfills for Neglected Small Cities in Developing Countries: The Semi-Mechanized Trench Method from Villanueva, Honduras. Waste Management, 32, 2535-2551. http://dx.doi.org/10.1016/j.wasman.2012.07.030 
[20] Vidanaarachchi, C.K., Yuen, S.T.S. and Pilapitiya, S. (2006) Municipal Solid Waste in the Southern Province of Sri Lanka: Problems, Issues and Challenges. Waste Management, 26, 920-930.

http://dx.doi.org/10.1016/j.wasman.2005.09.013

[21] Damghani, A.M., Savarypour, G., Zand, E. and Deihimfard, R. (2008) Municipal Solid Waste Management in Tehran: Current Practices, Opportunities and Challenges. Waste Management, 28, 929-934. http://dx.doi.org/10.1016/j.wasman.2007.06.010

[22] Mallawarachchi, H. and Karunasena, G. (2012) Electronic and Electrical Waste Management in Sri Lanka: Suggestions for National Policy Enhancements. Resource, Conservation, and Recycling, 68, 44-53. http://dx.doi.org/10.1016/j.resconrec.2012.08.003

[23] Department of Census and Statistics (2012) Census of Population and Housing in 2012. DCS, Colombo.

[24] Bruner, C.R. (1998) Design of Incinerator System. McGraw Hill, New York. 
Scientific Research Publishing (SCIRP) is one of the largest Open Access journal publishers. It is currently publishing more than 200 open access, online, peer-reviewed journals covering a wide range of academic disciplines. SCIRP serves the worldwide academic communities and contributes to the progress and application of science with its publication.

Other selected journals from SCIRP are listed as below. Submit your manuscript to us via either submit@scirp.org or Online Submission Portal.
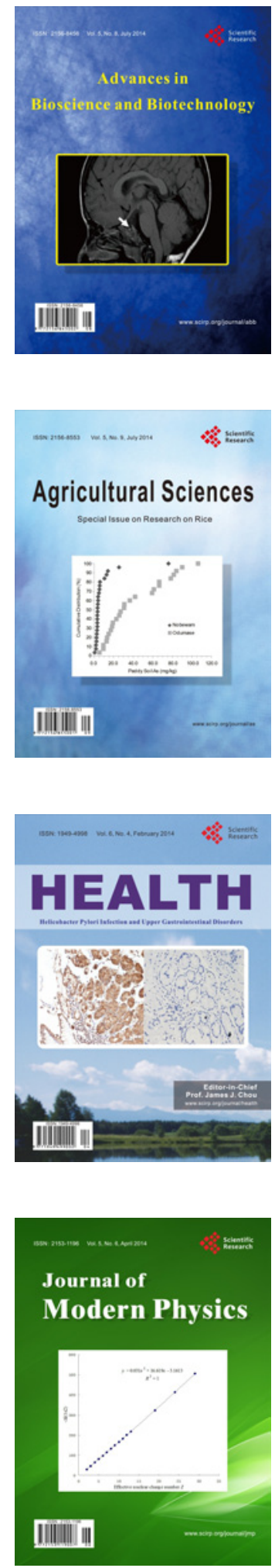
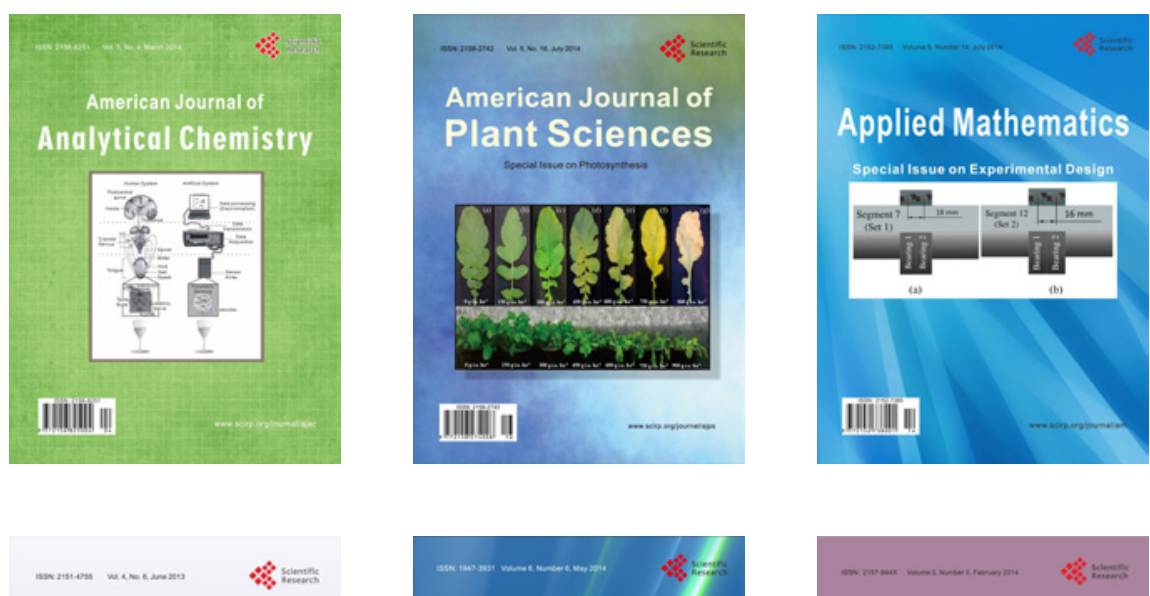

Creative Education
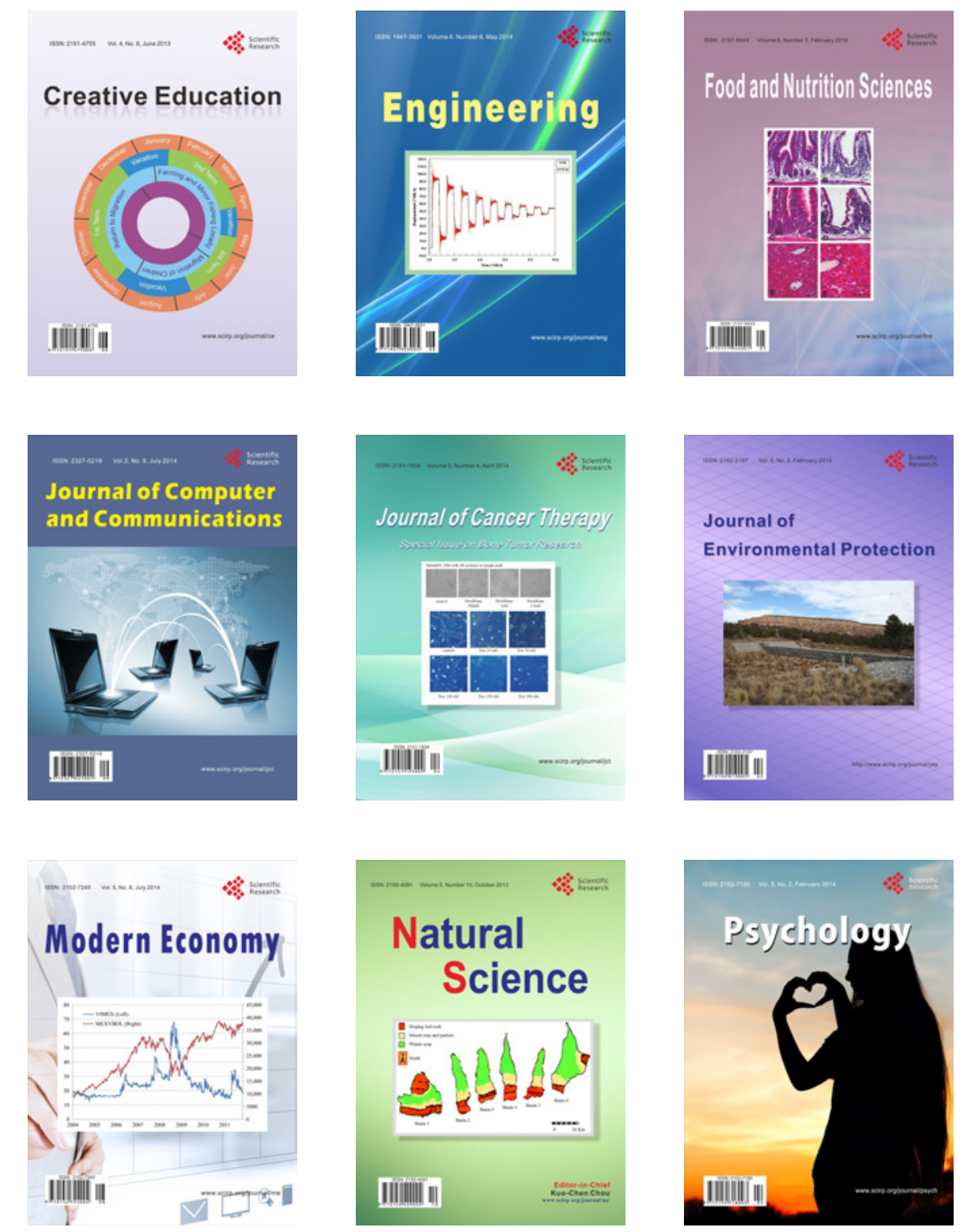